\title{
'Comparison of Conventional versus Accelerated Fractions of Radiotherapy per Week for Squamous Cell Carcinoma of the Head and Neck'
}

\author{
${ }^{1}$ Department of Radiation Oncology, Dr S. N. Medical College, India \\ ${ }^{2}$ Senior Professor \& Head, Department of Radiation Oncology, S N Medical College, India \\ ${ }^{3}$ Senior Resident, Department of Radiological Physics, India \\ ${ }^{4}$ Senior Resident, Department of Radiation Oncology
}

Manoj kumar suman ${ }^{1 *}$, Pradeep Gaur², Prabhat krishna Sharma ${ }^{3}$, Velmurugan $\mathrm{K}^{3}$ and Abhishek Sharma ${ }^{5}$

Submission: November 23, 2020; Published: December 15, 2020

*Corresponding author: Manoj kumar suman, Resident Doctor, Rajasthan University of Health Sciences, Dr. S.N. Medical College \& AGH, Shastri Nagar, Sardarpura, Jodhpur-342001, Rajasthan, India

\begin{abstract}
Purpose: In Indian scenario Head and neck cancer is the second most cancer. As compared to female it is more common in male. In radiotherapy, conventional fractionation $(5 \mathrm{Fx} /$ week) and accelerated fractionation $(6 \mathrm{fx} /$ week) is being advocated. Squamous cell carcinoma of the Head and neck cancer is predominantly a loco regional disease. The objective of the present study is comparison between conventional $\mathrm{v} / \mathrm{s}$ accelerated fractions of radiotherapy in Squamous cell carcinoma of locally advanced Head and neck cancer.

Methods: This prospective randomized single Institutional study done from July 2018 to November 2019 at Mathura Das Mathur Hospital, Jodhpur has compared the accelerated fractionation (66 Gy/33\#, 6 days per week) with conventional fractionation (66 Gy/33 \#, 5 days per week) in Squamous cell carcinoma of Head and neck patients. Comparison was done between the two radiotherapy schedules comprising of 25 patients each Arm.

Results and Conclusion: The rate of grade I and II toxicities were similar in both arms. In the present study has proved that accelerated fraction provide benefit mainly by local tumor control. The rates of grade III toxicities were significantly more in accelerated arm. So, when selecting the patients for these regimes' institutional workload, disease status and patients related factors should be considered.

Abbreviations: AJCC: American Joint Committee on Cancer; BOT: Base of Tongue; BMI: Body Mass Index; CR: Complete Response; ECOG: Eastern Co-operative Oncology Group; FOM: Floor of Mouth; Gy: Gray; HP: Hypopharynx; LFT: Liver Function Test; MD: Moderately differentiated; PD: Poorly differentiated; PR: Partial Response; R: Rural; RMT: Retromolar Triagone; RTOG: Radiation Therapy Oncology Group; RT: Radiotherapy; SD: Stable disease; SP: Soft Palate; U: Urban; WD: Well differentiated; WHO: World Health Organization
\end{abstract}

\section{Introduction}

Head and Neck cancer is most common malignant disease in the world. Worldwide cancer research is on the rise with studies maneuvering important issues impacting management of disease. The recent scenario different diagnostic methodologies, surgical techniques, and adjuvant treatment strategies has improved overall survival in head and neck cancer worldwide [1]. In Indian scenario head and neck cancers come under the second most usual cancers [2]. Head and neck cancers arise from the lining membrane of the upper aero-digestive tract. Approximately Ninety percent of the head and neck cancers are of squamous cell type [3]. The most frequent squamous-cell carcinomas of the oral cavity are pharynx, larynx, and the less common are the tumors of the nasal cavity, salivary glands and para nasal sinuses. Division of the single dose into multiple doses spares normal tissue through repair of SLD (Sub-lethal damage) \& repopulation of cells. Concurrently, fractionation increases tumor damage 
through re-oxygenation \& redistribution of tumor cells. Hence, a balance is achieved between the response of tumor \& early \& late reacting normal tissue. Most common fractionation for curative radiotherapy is 1.8 to $2.2 \mathrm{~Gy}$ [4].

The delivery of radiation in small-dose fractions (2-3 times per day) is aims to improve the therapeutic ratio by reducing the dose given in each fraction, so as to minimize the late side effects while also permitting an increased total dose to the tumor bed. It is an alternative to hyper fractionation. Thus, the review quite clearly points out the benefits of altered fractionation schedules over conventional fractionation schedules either in the form of survival advantage, toxicity profile or logistic advantage. Thus, the studies quite clearly mention out the benefits of altered fractionation schedules over conventional fractionation schedules either in the form of survival advantage, toxicity profile or logistic advantage. Many hypotheses have been developed to find the suitable fractionation scheme, but they all were failed to find out an ideal scheme, due to the shortcoming in tumor control, overall survival or aggravated toxicities [5,6]. The local control rate and toxicity is the quintessence in developing an ideal fractionation scheme. Though majority of studies had a better DFS (disease free survival) with Hyper fractionation over accelerated fractionation, the logistics to deliver hyper fractionation makes it an unsuitable regimen, thus especially in the high-volume Indian cancer centers of constrained resource like our institution carried out a study to evaluate the benefits of accelerated fractionation.

\section{Materials and Methods}

In the present study, which was performed at Mathura Das Mathura Hospital, Jodhpur a total of 50 histological proven cases of squamous cell carcinoma of head \& neck cancers (HNC), stage
III and IVa were randomized into two arms, Arm P and Arm Q. Arm $P$ patients received conventional regime of radiotherapy $(2$ Gray/fraction for 5 days/week, Monday to Friday). All the Patients in the study were treated with radiation Dose 66 Gy in 33 fractions by external beam Radiation therapy (EBRT) on Theraton $780 \mathrm{E}$ telecobalt unit with average photon energy of $1.25 \mathrm{MeV}$ and SSD of $80 \mathrm{~cm}$. Arm Q patients received accelerated radiotherapy regime (2 Gray/fraction for 6 days/ week, Monday to Saturday). Patients in each arm also received weekly cisplatin $(40 \mathrm{mg} / \mathrm{m} 2)$. Overall treatment time for Arm P was approximately 47 days while in Arm B it was almost 40 days. Before starting the treatment of patients were examined by defined institutional clinical protocol. The Patient has to undergo through the complete history and general physical examination with an clinical performance status, and dental status. Complete history of presenting complaints, habit of tobacco chewing, or smoking was asked. Any significant past history or family history related to malignancy was recorded. General physical condition, nutritional status, anemia and oral hygiene were also evaluated and clinical examination for evidence of lymphadenopathy and systemic examination to exclude any evidence of distant metastasis was done for each patient. Local examination of oral cavity was done under aseptic conditions. Primary site of malignancy was inspected for site, size, shape, surface, borders, margins, base, infiltration to surrounding structures and any signs of inflammation. X-ray Soft tissue neck, X-ray Chest, Ultra-sonography abdomen and CECT Scan/MRI of head and neck were used for disease assement and evaluation. Careful examination of lymphatic system of head \& neck was performed for the level of lymph nodes (level 1 to 5 ) involved, number, size, consistency, mobility, and any sign of inflammation. All patients were staged according to the American Joint committee on cancer staging system, 8th Edition.

\section{Result \& Discussion}

Table 1

\begin{tabular}{|c|c|c|c|c|c|c|c|c|}
\hline \multirow[b]{2}{*}{ Response } & \multicolumn{4}{|c|}{ Arm P } & \multicolumn{4}{|c|}{ Arm Q } \\
\hline & $\begin{array}{l}\text { AFTER Treatment } \\
\text { completion }\end{array}$ & $1^{\text {st }}$ month & $3^{\text {rd }}$ month & $6^{\text {th }}$ month & $\begin{array}{l}\text { AFTER Treatment } \\
\text { Completion }\end{array}$ & $1^{\text {st }}$ month & $3^{\text {rd }}$ month & $6^{\text {th }}$ month \\
\hline CR & $\begin{array}{c}12 \\
(48 \%)\end{array}$ & $\begin{array}{c}12 \\
(48 \%)\end{array}$ & $\begin{array}{c}12 \\
(48 \%)\end{array}$ & $\begin{array}{c}13 \\
(52 \%)\end{array}$ & $\begin{array}{c}08 \\
(32 \%)\end{array}$ & $\begin{array}{c}09 \\
(36 \%)\end{array}$ & $\begin{array}{c}10 \\
(40 \%)\end{array}$ & $\begin{array}{c}10 \\
(40 \%)\end{array}$ \\
\hline PR & $\begin{array}{c}12 \\
(48 \%)\end{array}$ & $\begin{array}{c}12 \\
(48 \%)\end{array}$ & $\begin{array}{c}12 \\
(48 \%)\end{array}$ & $\begin{array}{c}12 \\
(48 \%)\end{array}$ & $\begin{array}{c}17 \\
(68 \%)\end{array}$ & $\begin{array}{c}16 \\
(64 \%)\end{array}$ & $\begin{array}{c}15 \\
(60 \%)\end{array}$ & $\begin{array}{c}15 \\
(60 \%)\end{array}$ \\
\hline SD & $\begin{array}{c}1 \\
(4 \%)\end{array}$ & $\begin{array}{c}1 \\
(4 \%)\end{array}$ & $\begin{array}{c}1 \\
(4 \%)\end{array}$ & $\begin{array}{c}0 \\
0 \%) \\
(0 \%)\end{array}$ & $\begin{array}{c}0 \\
(0 \%)\end{array}$ & $\begin{array}{c}0 \\
0 \%\end{array}$ & $\begin{array}{c}0 \\
0 \%) \\
(0 \%)\end{array}$ & $\begin{array}{c}0 \\
0 \%)\end{array}$ \\
\hline PD & 0 & 0 & 0 & 0 & 0 & 0 & 0 & 0 \\
\hline Total & 25 & 25 & 25 & 24 & 25 & 25 & 25 & 25 \\
\hline
\end{tabular}

Aim of the study was to compare loco-regional tumor control in five fractions vs six fractions per week radiotherapy at 6 month and to find out toxicities in five fractions vs six fractions per week radiotherapy regimes. Reduced overall treatment time is expected to counteract the accelerated growth and thereby improve loco-regional control [7]. Such shorter overall treatment days without a dose reduction can be achieved either by applying a higher dose per fraction or by applying more fractions per week $[8,9]$. In this study, complete response for local site at after treatment completion and at 1 st month was $48 \%, 48 \%$ in arm-P and $32 \%, 36 \%$ patients in arm-Q respectively (Table 1 ). At $3^{\text {rd }}$ and $6^{\text {th }}$ month complete response was $48 \%, 56 \%$ in arm-P and 


\section{Cancer Therapy \& Oncology International Journal}

$40 \%, 40 \%$ patients in arm-Q. The rates of grade I and II toxicities (Early grade) were similar in both arms. The rates of grade III skin reactions and mucositis (Tables $2 \& 3$ ) were significantly higher in Arm Q and these patients also took more time to recover from toxicities. No grade IV toxicity was seen in any arm.

Table 2

\begin{tabular}{|c|c|c|c|c|c|c|c|c|}
\hline Skin reaction & AFTER Treatment & $\mathbf{1}^{\text {st }}$ month & $\mathbf{3}^{\text {rd }}$ month & $\mathbf{6}^{\text {th }}$ month & AFTER Treatment & $\mathbf{1}^{\text {st }}$ month & $3^{\text {rd }}$ month & $\mathbf{6}^{\text {th }}$ month \\
\hline $\mathbf{0}$ & 2 & 0 & 12 & 16 & 0 & 0 & 0 & 18 \\
\hline I & 9 & 11 & 8 & 6 & 8 & 3 & 2 & 3 \\
\hline II & 11 & 8 & 4 & 1 & 7 & 11 & 18 & 3 \\
\hline III & 3 & 6 & 1 & 1 & 10 & 11 & 5 \\
\hline IV & 0 & 0 & 0 & 0 & 0 & 0 & 0 \\
\hline
\end{tabular}

Table 3

\begin{tabular}{|c|c|c|c|c|c|c|c|c|}
\hline \multirow{2}{*}{ Parameters/ grading } & \multicolumn{3}{|c|}{ Arm P } & \multicolumn{5}{c|}{ Arm Q } \\
\cline { 2 - 10 } & $\begin{array}{c}\text { AFTER Treatment } \\
\text { completion }\end{array}$ & $\mathbf{1}^{\text {st }}$ month & $\begin{array}{c}3^{\text {rd }} \\
\text { month }\end{array}$ & $\mathbf{6}^{\text {th }}$ month & $\begin{array}{c}\text { AFTER Treat- } \\
\text { ment }\end{array}$ & $1^{\text {st }}$ month & $\begin{array}{c}3^{\text {rd }} \\
\text { month }\end{array}$ & $\mathbf{6}^{\text {th }}$ month \\
\hline Mucositis & & & & & & & & \\
\hline 0 & 1 & 1 & 18 & 24 & 0 & 0 & 17 & 23 \\
\hline I & 12 & 9 & 6 & 01 & 11 & 10 & 5 & 2 \\
\hline II & 10 & 11 & 1 & 0 & 10 & 11 & 3 & 0 \\
\hline III & 2 & 4 & 0 & 0 & 4 & 4 & 0 & 0 \\
\hline IV & 0 & 0 & 0 & 0 & 0 & 0 & 0 & 0 \\
\hline
\end{tabular}

\section{Summary \& conclusion}

This prospective clinical study was undertaken to evaluate and compare local tumor control, acute toxicities and progression free survival by five fractions $\mathrm{v} / \mathrm{s}$ six fractions per week radiotherapy in locally advanced head and neck cancer. For this, 50 cases of histologically proven squamous cell carcinoma were randomized into two arms: - (Table 4)

Table 4

\begin{tabular}{|c|c|}
\hline Conventional arm (Control): Arm $\mathbf{P}$ & Hyperfractionated arm (Study): Arm $\mathbf{Q}$ \\
\hline Dose: 2 Gy/fx., $1 \mathrm{fx} . /$ day, 5 days a week & Dose: 2 Gy/fx., $1 \mathrm{fx} . /$ day, 6 days a week \\
\hline Total tumor dose: 66 Gy/33fractions & Total tumor dose: 66 Gy/33 fractions \\
\hline
\end{tabular}

To conclude, results of this study suggest that accelerated treatment provide benefit mainly by local control while it has no significant effect on nodal control. Rates of grade III toxicities were significantly more in accelerated arm. The results were similar with previous similar studies. So, when choosing patients for any of these regimes, institutional workload, disease status and patient related factors should be considered. To understand the longterm control and toxicities when using accelerated radiotherapy, a longer follow-up and a larger sample size is required. Tumor heterogenicity is another factor which affects outcome of results, so it should also be considered before deciding regimes.

\section{References}

1. Tuljapurkar V, Dhar H, Aseem Mishra, Swagnik Chakraborti, Pankaj Chaturvedi, et al. (2016) The Indian scenario of head and neck oncology - Challenging the dogmas. South Asian J Cancer 5(3): 105-110.

2. Siddiqui MS, Chandra R, Abdul Aziz, Saurav Suman (2012) Epidemiology and Histopathological Spectrum of Head and Neck Cancers in Bihar, a State of Eastern India. Asian Pac J Cancer Prev 13(8): 3949-3953.

3. Majumder D, Choudhury K, Das P, Kundu S, Mitra D (2013) Different fractionation schedules of radiotherapy in locally advanced head and neck malignancy: A prospective randomized study to compare the results of treatment and toxicities of different protocols. South Asian J Cancer 2(1): 31-35.

4. Koulis TA, Dang A, C Speers, RA Olson (2018) Factors affecting radiotherapy prescribing patterns in the post-mastectomy setting. Curr Oncol 25(2): e146-e151.

5. Nguyen LN, Ang KK (2002) Radiotherapy for cancer of the head and neck: altered fractionation regimens. Lancet Oncol 3(11): 693-701.

6. Bernier J Bentzen SM (2003) Altered fractionation and combined radio-chemotherapy approaches: pioneering new opportunities in head and neck oncology. Eur J Cancer 39: 560-571.

7. Hansen O, Overgaard J, Hansen HS, Overgaard M, Hoyer M, et al. (1997) Importance of overall treatment time for the outcome of radiotherapy of advanced head and neck carcinoma: dependency on tumor differentiation. Radiother Oncol 43: 47-51. 


\section{Cancer Therapy \& Oncology International Journal}

8. Nguyen LN, Ang KK (2002) Radiotherapy for cancer of the head and neck: altered fractionation regimens. Lancet Oncol 3: 693-701.
9. Bernier J Bentzen SM (2003) Altered fractionation and combined radiochemotherapy approaches: pioneering new opportunities in head and neck oncology. Eur J Cancer 39(5): 560-571.
Your next submission with Juniper Publishers will reach you the below assets

- Quality Editorial service

- Swift Peer Review

- Reprints availability

- E-prints Service

- Manuscript Podcast for convenient understanding

- Global attainment for your research

- Manuscript accessibility in different formats (Pdf, E-pub, Full Text, Audio)

- Unceasing customer service

Track the below URL for one-step submission https://juniperpublishers.com/online-submission.php 